\title{
INFLUENCE OF POLYETHYLENE FROM WASTE PURE WATER SACHET ON PROPERTIES OF HOT MIX ASPHALT
}

\author{
A. A. Murana ${ }^{1, *}$, A. A. Abdulkarim ${ }^{2}$ and A. T. Olowosulu ${ }^{3}$ \\ 1,3, Department of Civil Engineering, Ahmadu Bello University, Zaria, Kaduna State, NIGERIA \\ 2, Department of Civil Engineering, Federal Polytechnic, OfFa, KWARA State, NIGERIA \\ E-mail addresses; ${ }^{1}$ fatinoyi2007@gmail.com; ${ }^{2}$ razaqamolegbe@gmail.com, ${ }^{3}$ atolowosulu@gmail.com
}

\begin{abstract}
This work evaluate the influence of waste pure water sachet (WPS) as a modifier in Hot Mix Asphalt (HMA). The properties of the constituent materials were determined. Modified HMA samples were prepared at varying concentration of 2, 4, 6, 8 and 10\% WPS content by weight of the Optimum Binder Content (OBC). The properties of the modified HMA were determined using Marshall Method of mix design. The properties of the constituent materials showed that they are suitable for HMA production. The modified bitumen showed an increase in softening point $(61-73.5 \%)$, flash point $\left(258-282^{\circ} \mathrm{C}\right)$, fire point $\left(289-311^{\circ} \mathrm{C}\right)$ and ductility $(92.67-$ $118.67 \mathrm{~cm}$ ) as the WPS content increases from $2 \%$ to $10 \%$ while decrease in penetration (62.33 $-56.5 \mathrm{~mm}$ ) as WPS content increases from $2 \%$ to $6 \%$. Stability and Bulk density increases from $4.64 \mathrm{kN}$ to $8.84 \mathrm{kN}$ and $2.21 \mathrm{~g} / \mathrm{cm}^{3}$ to $2.34 \mathrm{~g} / \mathrm{cm}^{3}$ respectively while flow, voids in mineral aggregates (VMA) and Air voids decreases from 3.6 to $2.98 \mathrm{~mm}, 23.85$ to $20.16 \%$ and 19.73 to $13.97 \%$ respectively as the WPS content was increased from 2 to $8 \%$. An optimum polyethylene from WPS modifier content of $8 \%$ by weight of the OBC is recommended for use in the HMA.
\end{abstract}

Keywords: Bitumen, Hot Mix Asphalt, Pure Water Sachet, modified bitumen, Marshall Properties, Polyethylene.

\section{INTRODUCTION}

Road infrastructure is a major component of landbased transportation, thus in order to maintain a good one, a very durable high-quality road pavement is required. Various researches towards improving pavement quality and performance have been conducted $[1,2]$.

Most of the roads in Nigeria are subjected to heavier loads than designed axle loading due to increase in number of commercial trucks resulting in constant pavement failure. Additionally, ageing and deterioration may be induced by climatic and environmental factors which include moisture, temperature, radiation and chemical attack which negatively impacts on physical and chemical properties of asphalt [3]. Therefore, there is an increasing need to strengthen and extend pavement service life, because of daily increasing traffic on the highways.
Awwad and Shbeeb [4] indicated that the modified mixture has a higher stability and VMA compared to the non-modified mixtures and thus positively influence the rutting resistance of these mixtures. Gawande, et al. [5] observed that use of modified bitumen with the addition of processed waste plastic of about $5-10 \%$ by weight of bitumen helps in improving the longevity and pavement performance with marginal saving in bitumen usage. Khan and Gundaliya [6] stated that the process of modification of bitumen with waste polythene enhances resistance to cracking, pothole formation and rutting by increasing softening point, hardness and reducing stripping due to water, thereby improving the general performance of roads over a long period of time. Pareek, et al. [7] observed a significant improvement in case of rutting resistance, indirect tensile strength and resilient modulus of the bituminous concrete mix with polymer modified

\footnotetext{
* Corresponding author, tel: $+234-803-637-6697$
} 
bitumen. Sabina, et al. [8] observed that the results of marshal stability and retained stability of polyethylene modified bituminous concrete mix increases 1.21 and 1.18 times higher than that of conventional mix by using 8 and $15 \%$ (by weight of bitumen) polythene with respect to 60/70 penetration grade of bitumen. Vasudevan [9] reported that polymer bitumen blend is a better binder compared to plain bitumen resulting higher Marshall Stability and decreasing the possibilities of potholes formation. Verma [10] reported that while a normal "highway quality" road lasts four to five years, plastic-bitumen roads can last up to 10 years where temperatures frequently cross $50^{\circ} \mathrm{C}$ and torrential rains create havoc, leaving most of the roads with big potholes. Moghadam and Karim [11] concluded that Polyethylene Terephthalate (PET) reinforced mixtures possess higher stability value, flow, fatigue life in comparison with the mixtures without PET. Sui and Chen [12] concluded that there is improvement on high temperature stability, low temperature cracking resistance and water resistance on modification and evaluation of polyethylene as additive in the technical, economic and environmental aspects. Al-Hadidy and Yi-Qui [13] indicated that modified binders showed higher softening point, keeping the values of ductility at minimum range of specification of $(100+\mathrm{cm})$, and cause a reduction in percentage loss of weight due to heat and air (i.e. increase durability of original asphalt). Panda and Mazumdar [14] observed that penetration, ductility, and specific gravity of the modified binders decreased as compared with unmodified bitumen while the softening point temperature, temperature susceptibility and viscosity increased.

Plastics wastes are on the rise yearly and are creating a nuisance in the immediate environment. Today, availability of plastic waste is enormous; because nearly $50 \%$ to $60 \%$ of total plastic are consumed as packing material [15]. Utilization of this waste for purpose of construction will no doubt be a welcome development. This work was to evaluate the influence of polyethylene from WPS as a modifier for bitumen in HMA.

\section{MATERIALS AND METHODS}

The materials used are bitumen, modifier (polyethylene from WPS) and aggregates.
Experimental methods that were employed are: Penetration [16], flash and fire point [17], Softening point [18], Ductility [19], Viscosity [20], Specific gravity [21] and Marshall Stability tests [22].

The following tests were conducted on the coarse aggregate. Aggregate impact value [23], Aggregate crushing value [24], Los Angeles abrasion [25], Flakiness index [26], Elongation index [27] and Specific gravity [28]. Particle size analysis [29, 30] and specific gravity [31] were conducted on the fine aggregates and mineral filler.

The WPS were collected; washed and cleaned by putting them in hot water for 3-4 hours. They were then dried. The dried WPS were cut into tiny pieces of size $50 \times 5 \mathrm{~mm}$ maximum.

\section{RESULTS AND DISCUSSION}

\subsection{Aggregates}

The results of quality control tests conducted on the aggregates are as presented in Table 1. Based on its index properties, the aggregate is of low plasticity and falls within the range specified by the Nigerian standards for Roads and Bridges, [32] to be used for asphalt concrete construction purposes.

\subsubsection{Particle Size Analysis of Aggregates}

The result of the particle size analysis conducted on the aggregates materials are as presented in Figure 1. It was observed that a predominant percent of approximately $90.5 \%$ were retained on sieve No.8 $(2.36 \mathrm{~mm})$ for the coarse aggregate material, and $92.611 \%$ passed sieve No.8 $(2.36 \mathrm{~mm})$ but retained on sieve No $200(0.075 \mathrm{~mm})$ for the fine aggregate material and $74.627 \%$ passed sieve No. 200 and was retained on the pan for the mineral filler material respectively. This is according with the required limits specified for aggregates material [33].

The proportioning of aggregate was done using the trial-and-error method. The proportions that finally gave the required gradations were obtained to be 52.6, 38.4, and $9.0 \%$ for coarse, fine aggregates and mineral filler respectively

\subsection{Pure Bitumen}

The results of tests carried out on the bitumen are as presented in Table 2 . The grade of the bitumen is $60 / 70$ which make suitable for use in HMA production. 
Influence of Polyethylene from Waste Pure Water Sachet on Properties of Hot Mix Asphalt, A. A. Murana, et. al

Table 1: Results of the Quality Control Tests Performed on Aggregates

\begin{tabular}{llcccc}
\hline S/N & Test Conducted & Results & Unit & Specification [32] & Comment \\
\hline 1. & Impact value & 29.19 & $\%$ & $<30$ & Satisfactory \\
2. & Crushing value & 28.00 & $\%$ & $<30$ & Satisfactory \\
3. & Abrasion value & 24.00 & $\%$ & $<30$ & Satisfactory \\
4. & Elongation index & 24.48 & $\%$ & $<35$ & Satisfactory \\
5. & Flakiness index & 24.87 & $\%$ & $<30$ & Satisfactory \\
6. & Specific gravity (fine) & 2.63 & $\mathrm{Nil}$ & $2.5-2.9$ & Satisfactory \\
7. & Specific gravity (coarse) & 2.94 & $\mathrm{Nil}$ & $2.5-2.9$ & Satisfactory \\
\hline
\end{tabular}

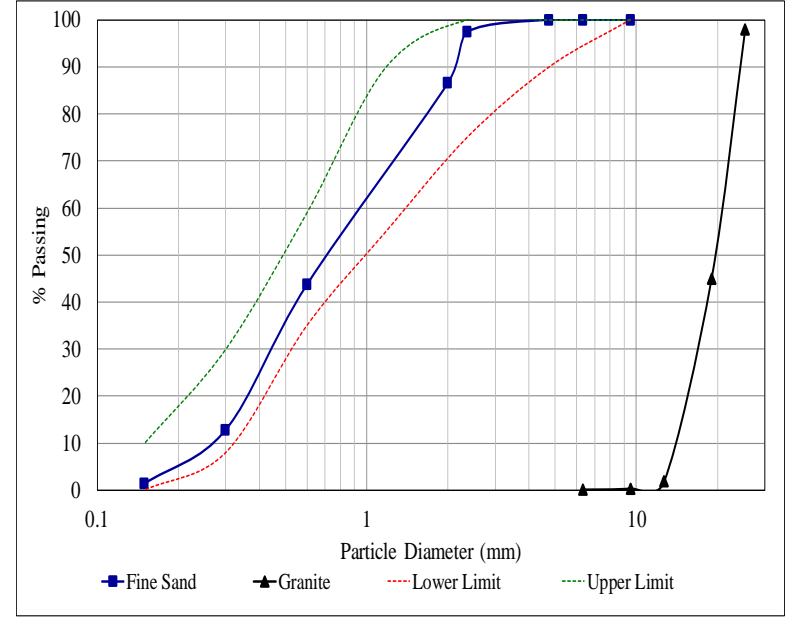

Figure 1: Particle Distribution Curve

\subsection{Effects of the WPS on the Properties of Bitumen}

The effect of addition of waste polyethylene bags in form of water sachets has been studied by varying concentrations of polyethylene from $0 \%$ to $10 \%$ at an increment of $2 \%$. The summary of the results of the tests carried out are as presented in Table 3.

\subsubsection{Effects of Modifier on the Penetration} From Table 3, it was observed that the penetration value decreases with an addition of WPS. This decreasing trend is in line with the works of [34], [35] who worked on virgin waste polymer modified bitumen for HMA. Panda and Mazumdar [14] observed that the penetration of modified bitumen decreased as compared with unmodified bitumen.

\subsubsection{Effects of the Modifier on the Softening point}

Table 3 shows that as the WPS increases, the softening point also increases. This phenomenon can be attributed to the fact that the bitumen becomes less susceptible to temperature changes as the modifier content increased which is an indication of high rutting resistance and bleeding of binder at temperatures above the softening point. This trend is in line with $[6,13,14,34,36,37]$ who observed that the softening point of the modified binders increased as compared with unmodified bitumen.

Table 2 Consistency Test Results on Pure Bitumen

\begin{tabular}{lllll}
\hline S/N & Test Conducted & Unit & Result & Specification \\
\hline 1 & Penetration & $0.1 \mathrm{~mm}$ & 68.9 & $60-70$ \\
2 & Softening point & ${ }^{\circ} \mathrm{C}$ & 48.5 & $48-56$ \\
3 & Ductility @ $25^{\circ} \mathrm{C}$ & $\mathrm{Cm}$ & 105 & 100 (Minimum) \\
4 & Specific gravity & NIL & 1.013 & $1.01-1.06$ \\
5 & Flash-point & ${ }^{\circ} \mathrm{C}$ & 230 & 250 (Minimum) \\
6 & Fire-point & ${ }^{\circ} \mathrm{C}$ & 256 & NIL \\
7 & Viscosity @ $60^{\circ} \mathrm{C}$ & Secs & 674 & NIL \\
\hline
\end{tabular}

Table 3: Summary of Results of the Consistency Test for the Modified Bitumen

\begin{tabular}{lllllll}
\hline S/NO & $\begin{array}{l}\text { PEB } \\
(\%)\end{array}$ & $\begin{array}{l}\text { Penetration } \\
(\mathrm{mm})\end{array}$ & $\begin{array}{l}\text { Ductility } \\
(\mathrm{cm})\end{array}$ & $\begin{array}{l}\text { Softening Point } \\
\left({ }^{\circ} \mathrm{C}\right)\end{array}$ & $\begin{array}{l}\text { Flash Point } \\
\left({ }^{\circ} \mathrm{C}\right)\end{array}$ & $\begin{array}{l}\text { Fire Point } \\
\left({ }^{\circ} \mathrm{C}\right)\end{array}$ \\
\hline 1 & 0 & 68.89 & 105.00 & 48.50 & 230.00 & 256.00 \\
2 & 2 & 62.33 & 92.67 & 61.00 & 258.00 & 289.00 \\
3 & 4 & 59.33 & 100.35 & 64.50 & 263.00 & 297.00 \\
4 & 6 & 56.50 & 105.33 & 66.50 & 270.00 & 305.00 \\
5 & 8 & 68.33 & 118.67 & 70.00 & 276.00 & 307.00 \\
6 & 10 & 104.50 & 97.00 & 73.50 & 282.00 & 311.00 \\
\hline
\end{tabular}




\subsubsection{Effects of the Modifier on the Ductility} From Table 3, the effect of WPS on ductility exhibits a decreasing fashion with increasing percentage in the modifier content. This can be attributed to the fact that as the percentage of modifier increases the bitumen became harder and less ductile. This concurs with $[14,34,35]$ whose works were on the effects of virgin polymer as a modifier of bitumen for HMA.

\subsubsection{Effects of the Modifier on the Flash and Fire point}

The variation of flash and fire point with modifier content is as shown in Table 3. It was observed that the effect of the modifier on the temperature increases with increasing percentage in modifier content. Panda and Mazumdar [14] observed that the temperature susceptibility of the modified binders increased as compared with unmodified bitumen.

\subsection{Influence of Polyethylene from WPS in HMA}

The Stability and flow values of the modified HMA are is as presented in Figures 2 and 3 while Figure 4 depicts the unit weight. The summary of result of Marshall Stability and Volume-void analysis are as presented in Table 4.

\subsubsection{Stability - WPS content relationship} From Figure 2, it was observed that highest stability value was obtained at $8 \%$ WPS content with an optimum value of $8.84 \mathrm{kN}$. This means that the addition of the modifier to the mix improved the stability of the HMA which could be attributed to hardening and decrease in the penetration of the pure bitumen in the mix. This translates to a hotmix with an increased resistance to plastic permanent deformation (rutting). The study agrees with the work of $[4,8,38]$ who study the effect of additives in HMA.

\subsubsection{Flow - WPS content relationship}

Figure 3 shows that the flow of the modified HMA decreases with increasing modifier content. This as a result of increased resistance to displacement the modifier had on the binder in the mix. This shows that modification of HMA using WPS reduces the rate of deformation. This agrees with the result of [39] who noted that reduction in flow suggests that polymer content has increased effect on the internal friction of the mix. It was observed that at optimum WPS, the flow was $2.98 \mathrm{~mm}$. This flow value lies within the specification $(2 \mathrm{~mm}-6 \mathrm{~mm})$ stated in the [32].

Table 4: Strength Properties of Polyethylene Modified Asphalt Concrete

\begin{tabular}{lcccccc}
\hline S/No & \% PEB & Stability $(\mathrm{kN})$ & Flow $(\mathrm{mm})$ & VMA & Pa & Bulk density, $\left(\mathrm{g} / \mathrm{cm}^{3}\right)$ \\
\hline 1 & 0 & 4.20 & 4 & 28.82 & 22.18 & 2.12 \\
2 & 2 & 4.64 & 3.6 & 23.85 & 19.73 & 2.21 \\
3 & 4 & 5.66 & 3.53 & 22.91 & 17.99 & 2.27 \\
4 & 6 & 6.23 & 3.12 & 21.52 & 16.85 & 2.29 \\
5 & 8 & 8.84 & 2.98 & 20.16 & 13.97 & 2.34 \\
6 & 10 & 7.13 & 3.23 & 22.51 & 13.6 & 2.33 \\
\hline
\end{tabular}

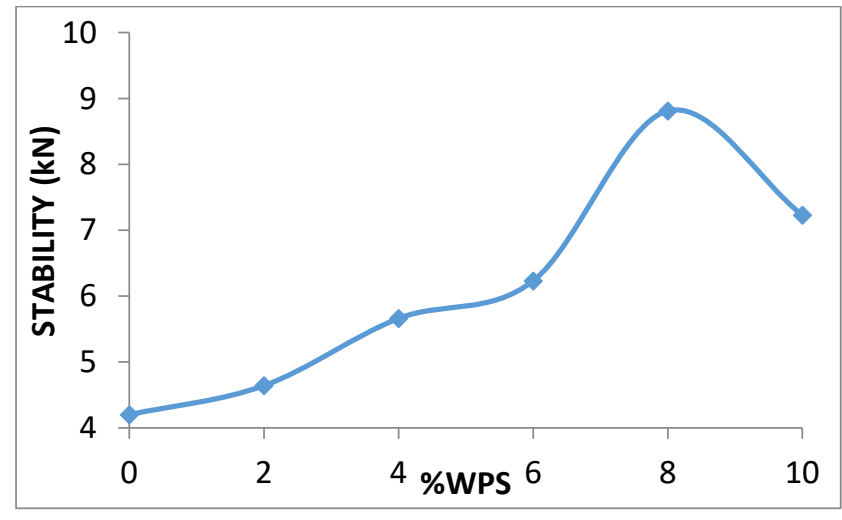

Figure 2: Variation of Stability with polyethylene from WPS on HMA

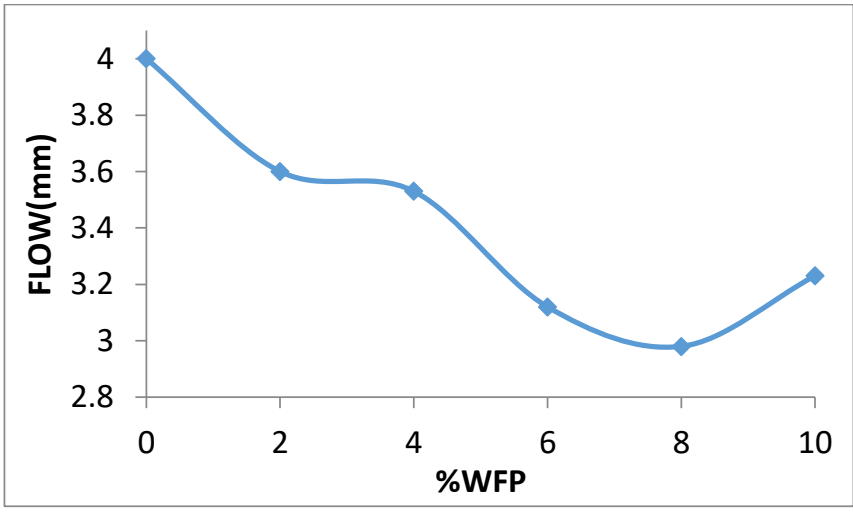

Figure 3: Variation of Flow with polyethylene from WPS on HMA

Vol. 39, No. 4, October 2020 


\subsubsection{Unit Weight - WPS content relationship}

The behaviour of the bulk unit weight with the varying percent in modifier content is shown in Figure 4. It was observed that the optimum WPS content was $8 \%$. At this point, the effect of WPS has increased the unit weight, bulk volume and compactness of asphalt concrete materials by filling up void spaces, thereby leading to reduction in voids. The study shows similar pattern with [39]and [38].

\subsubsection{VMA - WPS content relationship}

Figure 5 depicts the variation of VMA with modifier content. It can be observed that VMA decreases with increasing percentage WPS content up to $8 \%$, thereafter, further addition increases the value of VMA. This shows proper mixing of aggregate with the WPS in the mix. This showed a similar trend to that of [40] as VMA decreased to $17.5 \%$ at $2.5 \%$ before showing an increased pattern. Awwad \& Shbeeb [4] indicated that modified mixture has a lower VMA compared to non-modified mixtures and thus positively influence the rutting resistance of these mixtures.

\subsubsection{VIM - WPS content relationship}

Figure 6 depicts the variation of voids in the mix with modifier content. It can be observed that as percentage WFP contents increases, voids in the total mix lie within the specified range of $3-8 \%$. There's a sharp decline in the percentage of air voids at $6 \%$ and $8 \%$ WPS because more voids have been occupied by the mineral filler and the polyethylene bag. This follows a similar trend to the work of [41].

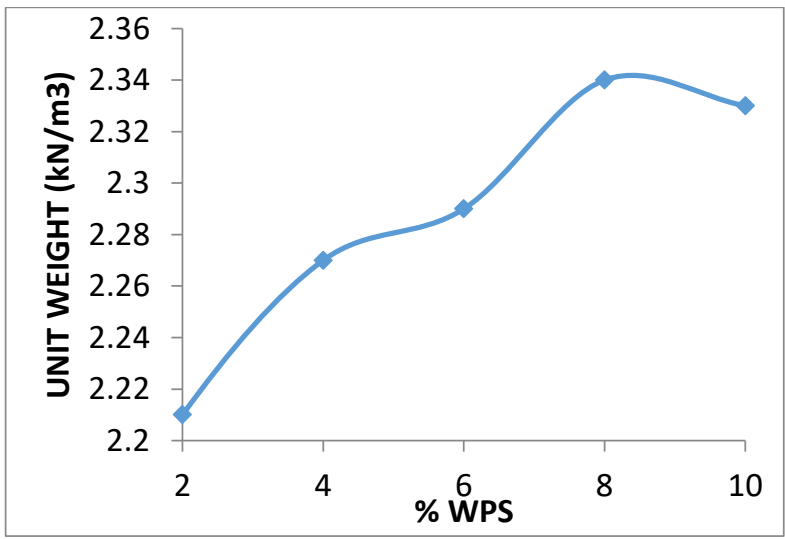

Figure 4: Variation of Unit Weight with polyethylene from WPS on HMA

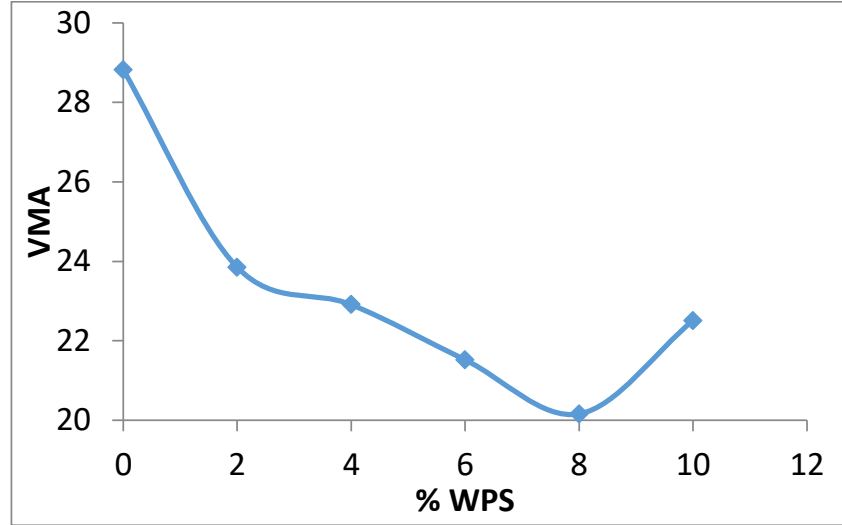

Figure 5: Variation of VMA with polyethylene from WPS on HMA

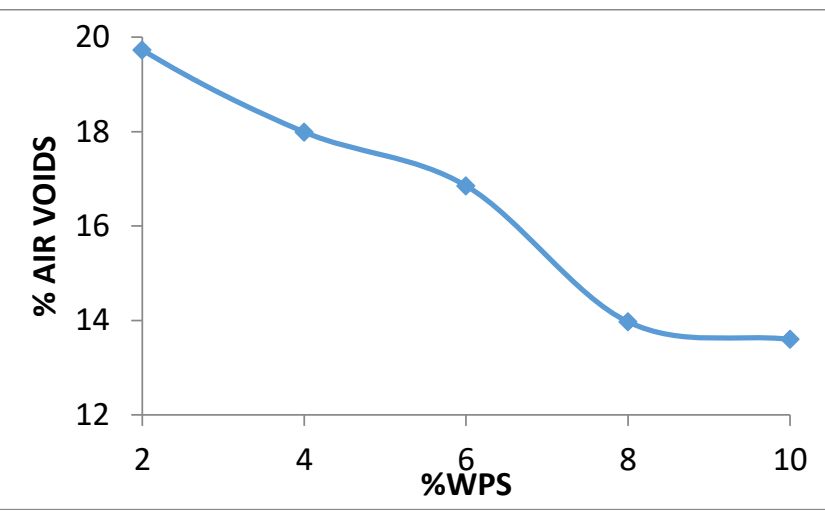

Figure 6: Variation of Percentage Air Voids with Polyethylene from WPS on HMA

\section{CONCLUSIONS}

1. It can be concluded that the optimum percentage polyethylene from waste pure water sachet in the modified mix was $8 \%$ of the total bitumen weight.

2. Polyethylene modifier offers better engineering properties and its usage as bitumen modifier which could serve as a means of managing the waste menace, and also increase its consistencies.

\section{REFERENCES}

[1] N. Nwakeze and M. Yusuff, "Transportation and Economic Growth in Nigeria," Journal of Research in National Development, vol. 8, no. 2, 2010.

[2] C. Olebune, "Transportation and Economic Growth in Nigeria," Journal of Research in National Development, vol. 8, no. 2, 2006.

[3] O. D. Afolayan and A. Olalekan, "Causes of failure on Nigerian roads"; A Review," Journal 
Influence of Polyethylene from Waste Pure Water Sachet on Properties of Hot Mix Asphalt, A. A. Murana, et. al

of Advancement in Engineering and Technology, vol. 5, no. 4, 2017.

[4] M. Awwad and L. Shbeeb, "The Use of Polyethylene in Hot Asphalt Mixtures," American Journal of Applied Sciences, vol. 4, no. 6, pp. 390-396, 2007.

[5] A. Gawande, G. Zamare, V. Renge, S. Tayde and G. Bharsakale, "Utilization of Waste Plastic in Asphalting of Roads," Scientific Reviews \& Chemical Communications, vol. 2, no. 2, pp. 147-157, 2012.

[6] I. Khan and P. Gundaliya, "Utilization of Waste Polyethylene Materials in Bituminous Concrete Mix for Improved Performance of Flexible Pavements," Indian Journal of Applied Research, vol. 1, pp. 85-86, 2011.

[7] A. Pareek, T. Gupta and R. K. Sharma, "Performance of Polymer Modified Bitumen for Flexible Pavements," International Journal of Structural and Civil Engineering Research, vol. 1, pp. 1-10, 2012.

[8] K. Sabina, K. T. A, C. Sangita, D. Sharma and B. Sharma, "Performance Evaluation of Waste Plastic/Polymers Modified Bituminous Concrete Mixes," Journal of Scientific \& Industrial Research, vol. 68, pp. 975-979, 2009.

[9] R. Vasudevan, "Utilization of waste plastics for flexible pavement," Indian Highways Indian Road Congress, vol. 34, no. 7, pp. 520, 2006.

[10] S. Verma, "Roads from Plastic Waste," The Indian Concrete Journal, pp. 43-44, 2008.

[11] T. B. Moghaddam and M. R. Karim, "Properties of SMA Mixtures Containing Waste Polyethylene Terephthalate," International Journal of Civil and Environmental Engineering, vol. 6, no. 2, pp. 170-173, 2012.

[12] Y. Sui and Z. Chen, "Application and Performance of Polyethylene Modifying Additive in Asphalt Mixture," in Third International Conference on Transportation Engineering (ICTE), 2012.

[13] A. Al-Hadidy and T. Yi-qiu, "Effect of polyethylene on life of flexible pavements.,"
Construction and Building Materials, vol. 23, pp. 1456-1464, 2009.

[14] M. Panda and M. Mazumdar, "Engineering Properties of EVA-Modified Bitumen Binder for Paving Mixes," Journal of Materials in Civil Engg, ASCE, vol. 11, no. 2, pp. 131-137, 1999.

[15] J. Zhu, "Polymer Modification of Bitumen: Advances and Challenges," European Polymer Journal, vol. 54, pp. 18-38, 2014.

[16] ASTM D5 / D5M-20, Standard Test Method for Penetration of Bituminous Materials, West Conshohocken, PA: ASTM international, 2020.

[17] ASTM D92-18, Standard Test Method for Flash and Fire points by Cleveland Open Cup Tester, vol. 05.01, West Conshohocken, PA: ASTM International, 2018.

[18] ASTM D36 / D36M-14, Standard Test Method for Softening Point of Bitumen (Ring-and-Ball Apparatus), vol. 04.04, West Conshohocken, PA: ASTM international, 2020.

[19] ASTM D113-17, Standard Test Method for Ductility of Asphalt Materials, vol. 04.03, West Conshohocken, Philadelphia.PA: ASTM International, 2017.

[20] ASTM D 4402, Standard test method for viscosity determination of asphalt at elevated temperatures using a rotational viscometer, West Conshohocken, Philadelphia, PA: ASTM International, 2015.

[21] BS EN 13108-1, Bituminous Mixtures-Material Specifications. Asphalt Concrete, London, United Kingdom: British Standard Institution, 2006.

[22] ASTM D6926-16, Standard Practice for Preparation of Asphalt Mixture Specimens Using Marshall Apparatus, West Conshohocken, Philadelphia, PA: American Society for Testing and Materials (ASTM) International, 2016.

[23] BS 812-112, Testing Aggregates. Methods for Determination of Aggregate Impact Value (AIV), London, United Kingdom: British Standard Institution, 1990, p. 14.

[24] BS 812-110, Testing Aggregates. Methods for Determination of Aggregate Crushing Value 
Influence of Polyethylene from Waste Pure Water Sachet on Properties of Hot Mix Asphalt, A. A. Murana, et. al

(ACV), London, United Kingdom: British Standard Institution, 1990, p. 12.

[25] ASTM C131 / C131M-20, Standard Test Method for Resistance to Degradation of Small-Size Coarse Aggregate by Abrasion and Impact in the Los Angeles Machine, West Conshohocken, PA: ASTM International, 2020.

[26] BS EN 933-3, Tests for Geometrical Properties of Aggregates, Determination of Particle Shape - Flakiness Index, London, United Kingdom: British Standard Institution, 1997.

[27] BS 812 105.2, Methods for Determination of Particle Shape, Elongation Index of Coarse Aggregate, London, United Kingdom: British Standard Institution, 1990.

[28] ASTM C127-15, Standard Test Method for Relative Density (Specific Gravity) and Absorption of Coarse Aggregate, West Conshohocken, PA: ASTM International, 2015.

[29] ASTM C136 /C136M-19, Standard Test Method for Sieve Analysis of Fine and Coarse Aggregates, West Conshohocken, PA: ASTM International, 2019.

[30] BS 812 103.1, Methods for Determination of Particle Size Distribution, London, United Kingdom: British Standard Institution, 1985.

[31] ASTM C128-15, Standard Test Method for Relative Density (Specific Gravity) and Absorption of Fine Aggregate, West Conshohocken, PA: ASTM International, 2015.

[32] FMWH, Nigerian General Specification for Roads and Bridges, vol. II, Lagos, Nigeria: Federal Ministry of Works and Housing (FMWH), 2016, p. 183.

[33] N. J. Garber and L. Hoel, Traffic and Highway Engineering, Fourth ed., Toronto Canada: University of Virginia, Cengage Learning, 2009.
[34] S. Z. Mohammed and K. Patil, "Comparative Study of Eva and Waste Polymer Modified Bitumen," World Academy of Science, Engineering and Technology, International Journal of Civil and Environmental Engineering, vol. 8, no. 1, p. 112, 2014.

[35] P. Kumar, T. Khan and M. Singh, "Study on EVA Modified Bitumen," Elixir Chemical. Engg, vol. 54A, pp. 12616-12618, 2013.

[36] O. Oyedepo and S. Oluwajana, "Evaluation of the properties of bitumen modified with tire waste," Nigerian Journal of Technology (NIJOTECH), vol. 33, no. 1, p. 121, 2014.

[37] R. M. Keymanesh, H. Ziari and B. Damyar, "Effect of waste EVA and waste CR on high temperature performance of bitumen," Petroleum Science and Technology, vol. 35, no. 15, pp. 1537-1541, 2017.

[38] S. Taih, "The Effect of Additives in Hot Asphalt Mixtures," Journal of Engineering and Development, vol. 15, no. 3, pp. 131-150, 2011.

[39] I. Aliyu, A. Usman, J. Kaura, M. Ashiru and I. Kingsley, "Polyethylene from Water Sachet as a Modifier in Hot Asphalt Mixture," Department of Civil Engineering, Ahmadu Bello University, Zaria, Nigeria, 2015.

[40] H. Z. Noor, I. Kamaruddin, M. Napiah and I. M. Tan, "Rheological Properties of Polyethylene and Polypropylene Modified Bitumen," International Journal of Civil and Environmental Engineering, vol. 3, no. 2, pp. 96-100, 2011.

[41] A. Mohammad, "Use of Waste Plastic Blended Bitumen for Road Construction and Maintenance," Master of Engineering thesis, Bangladesh University of Engineering and Technology, Bangladesh, 2012. 